\title{
FACILITY MANAGEMENT - INSTRUMENT FOR THE MANAGEMENT OF SUPPORT PROCESSES FOR HRM OUTSOURCING
}

The aim of this paper is to identify the most important motivational factors for Slovak employees in 2015. The relevant data was sourced using the questionnaire method. For data processing purposes, the descriptive method was used as well as statistical analysis. The calculated level of $p$-significance for the different motivational factors was calculated by utilising the $T$-test. The definition of the differences in the average level of importance of individual motivational factors is the result of the research. The obtained results allowed us to define which motivational factors affect the performance of the Slovak employees. On this basis, for Slovak companies, it is possible to design a uniform motivational program that will suit the majority of their employees. Under specific conditions, the local analyses can be more effective and their results can slightly differ from the general average. It is also possible that the motivational requirements of employees will change if their needs are satisfied. For this reason, according to the possibilities of the enterprise, it is recommended to update the motivational programs continuously.

Keywords: Facility management, support processes management, motivational program, T- test.

\section{Introduction}

Work motivation manifests itself in the relationship between a person and their work. Within the context of motivation, work can not only be seen as a source of livelihood. It is also an attribute that brings satisfaction from the actual performance of the work, from the working results, from the social status and the prestige of a profession, from the social relationships related to those professional activities and the awards that an employee receives as part of a team [1]. The American, John Adair [2], one of the world's experts in leadership, says that the motivation means providing a motive or incentive to a person to make this or that. By this activity [3], the behaviour of a person is initiated and their interest stimulated. Motivation is an important factor in the performance and efficiency of an enterprise and its managers spend a lot of energy, time and money on it [4]. Of greater significance is the assumption that motivation is a conscious and deliberate investment of energy in order to meet an objective that has been stated in advance. To achieve the objective, it is necessary to possess self-discipline, perseverance and patience. It is never understood as a duty. Energy, dynamism and intensity are conceived only as "own" behaviour, and in no case as something that is determined by strangers or through external inducements [5]. To motivate someone means to focus them on a specific objective and give them some satisfaction in terms of their needs, habits, interests, ideals and values orientation. The subject that is responsible for this motivation is the manager and the object of the motivation is the managed employee [6]. The main objective of work motivation being to motivate employees to perform well at optimum costs [7].

Authors such as Sekhar, et al. [8] have identified key motivational techniques in existing literature and determined their interconnection with the performance of organizations. These motivational techniques [9] can be considered as an important factor in dealing with potential improvements in employee motivation and thus the performance of an organization [10]. All authors of motivational techniques draw the same conclusion. If employees are provided with the correct motivational techniques at the right time, their morale and confidence rises and this has a direct positive impact on their individual performance and that of the organization too.

\footnotetext{
* ${ }^{1}$ Milos Hitka, ${ }^{2}$ Lenka Lizbetinova, ${ }^{3} \mathrm{Zdenek}$ Caha, ${ }^{4}$ Yan Xu

${ }^{1}$ Faculty of Wood Sciences and Technology, Technical University in Zvolen, Slovakia

${ }^{2}$ Faculty of Corporate Strategy, Institute of Technology and Business in Ceske Budejovice, Czech Republic

${ }^{3}$ Faculty of Corporate Strategy, Institute of Technology and Business in Ceske Budejovice, Czech Republic

${ }^{4}$ Department of Management, School of Economics and Management, North China University of Technology, China

E-mail: lizbetinova@mail.vstecb.cz
} 


\section{Objective and methodology}

Understanding the causes of motivation, knowing what its possibilities to influence are, and knowledge of the methods by which to regulate motivation, or even change it, is of particular importance for the effective management of people. In practice, motivating employees, professionals and managers can be realized on the basis of three approaches: individual, small-group and complex-group [11, 12 and 13].

In current human resources management, there is a conceptual dissemination and use of outsourcing. Managers of enterprises establish and implement personnel policies and strategies for various human resources activities in collaboration with their HR department. These activities include, for example, the creation and development of an organizations personnel planning and talent management, sourcing and selection, evaluation and pay, and safety and health of workers [14]. Every enterprise is therefore faced with the problem of how to manage this area as efficiently as possible [15]. In the majority of cases, companies respond by creating their own team of specialists to work with human resources. An alternative to this approach is to outsource the management of human resources [16]. The advantage to the enterprise of outsourcing is that it is able to benefit from the latest knowledge and practices in this area in combination with the high standard of work. It can also mean an increase in resource efficiency not only in financial terms, but also in terms of human resources [17]. Earmarking selected activities [18] of business management and handing responsibility for them to a subcontractor leads to a narrowing of the organization, a simplification of the management work of managers and a better use of resources. The organization does not have to expend resources to acquire property and can utilise them elsewhere and for other purposes. In addition, there is no need to invest in the training and retention of specialists because they are available as required. If the requirements for personnel grow or decline, companies are also not under immediate pressure to find a solution for either problem. The obligations and liabilities associated with them, the economic risks and the associated agenda are covered by the provider of the outsourced services. The nature of the outsourcing contract with the provider of outsourcing services is therefore very important.

The introduction and implementation of outsourcing in human resources management is not easy and requires management to take a considerate and sensitive approach. Some personnel activities may be provided by external contractors, personnel agencies or companies acting as service providers in these areas. They can provide specific personnel activities such as: determining specifications per employee; retrieval, search and selection of employees; creation of motivational programs; performance management of staff; career management; knowledge management; motivation and stimulation of employees; evaluation and measurement of work staff training; evaluation
[19]; remuneration of employees; creation of teams; creation of personnel information systems (as part of corporate information systems) [20]; conducting administrative affairs; personnel audits; personnel controlling; analysis of return on investment in human resources; social care of staff and improving staff performance [21].

Other activities including personnel planning, personnel policy and strategy, recruitment, orientation and placement of employees, creative management of employees, creation of corporate culture and philosophy, improving working relations, communication in the workplace, and the dismissal and retirement of employees should remain fully within the competence of an organization either in legal terms or in terms of strategy [22].

The decision on whether to outsource human resources management should therefore be based on a thorough analysis of the current situation within an organization and a comparison of how the selected personnel activities are provided in other businesses. This analysis also requires the reasons to be identified that show that it is more advantageous to transfer personnel activities to an outside agency. These reasons [23] may include:

cost savings - outsourced services are less expensive and the personnel department can be reduced in size;

HR employees can concentrate on key tasks - they are not distracted from their core tasks which results in quality gains; outsourced services are of a higher quality - there is an opportunity to gain know-how and experience that is not available within an enterprise.

\section{Methodology of research}

The aim of this work was to establish the actual and required level of employee motivation in Slovakia and attempt to identify which areas of employee motivation could be possibly outsourced. The research was conducted in 2015 on a research sample of 6,000 respondents from both the public and private sectors, including manufacturing and non-manufacturing enterprises, and service providers. The selection of respondents was carried out by simple random sampling, whereby each unit of the population had the same probability of being included in the sample. We used the questionnaire method to obtain the values for the motivating factors. This method allowed us to collect a lot of information in a short period of time. The first part of the questionnaire examined the qualifications and socio-demographic characteristics of the workers in the compared companies. This section provided basic data on the respondents ' age, gender, number of years worked in the enterprise, education level and position.

The second part of the questionnaire consisted of various motivational factors through which it was possible to establish information about the characteristics of the working environment, working conditions, application of evaluation and pay systems in the enterprise, personnel work within the enterprise, the system 
of social care and employee benefits, as well as on employee (dis)satisfaction, employees value orientations, attitudes to work and enterprise or relationships with colleagues. Our chosen motivational factors were arranged in alphabetical order to avoid influencing the respondent's responses. Employees could assign the level of importance of each motivational factor on a rating scale of one to five [24]. They were subsequently asked to also score the importance of the required status, as well as the actual status of each motivational factor. The desired status was understood to be the ideal form of motivation for employees, or what would motivate them to increase their performance. Similarly, the actual status was understood to represent the level of employee satisfaction with the current motivational factors within their enterprise.

The research sample consisted of 6,000 respondents from Slovakia. Table 1 shows the structure of the respondents. The questionnaires were evaluated using the program STATISTICA 7 [25]. Descriptive statistics were used to characterize the basic set. Statistical characteristics were calculated for each motivational factor (see Table 2).

These characteristics summarized information about the properties of the studied basic set into a smaller number of numerical characteristics in order to facilitate the mutual comparison of the files. The essential characteristics of each motivational factor were summarily described in terms of their dimensions [26 and 27] and the variability of their quantitative characters - arithmetic average (Equation 1), standard deviation $s_{x}$ and variation coefficient $\mathrm{V}$.

$\bar{X}=\frac{x_{1}+x_{2}+x_{3}+\cdots+x_{n}}{n}=\frac{1}{n} \sum_{i=1}^{n} x_{i}$

whereby:

$\mathrm{n}$ - is size of the statistical set,

$x_{i}-$ is average value of the $i-$ th statistical unit [23].

In addition to a simple comparison of the values of the descriptive characteristics, we carried out a test correlation of the arithmetic means and standard deviations of the basic sets. In the test, the significance of differences in the arithmetic means and standard deviations of the individual motivational factors of the monitored sets was checked at the selected level of significance. The verification showed that the differences found by the descriptors are not caused by the sample. We used a two-sample T-test to test the correlation averages of the motivational factors. Within the T-test, there were only two cases that were contrary to these findings and which were subject to whether the variances of the compared basic sets were equal or unequal $\left(\sigma_{1}^{2}=\sigma_{2}^{2}, \sigma_{1}^{2} \neq \sigma_{2}^{2}\right)$, or whether the investigated characteristics X1, X2 were dependent or independent. Before calculating the T-test, we used compliance tests of variance (F-test). Based on the results of the F-test, two-sample T-tests were performed for independent samples with equal or different variance. The null hypothesis was tested against the alternative hypothesis (Equation 2).
Breakdown of the research sample

Table 1

\begin{tabular}{ll}
\hline Gender & Number \\
\hline Male & 3179 \\
\hline Female & 2821 \\
\hline Age & Number \\
\hline
\end{tabular}

up to 30 years 1653

from 31 to 40 years 1829

from 41 to 50 years 1594

51 years and over 924

\begin{tabular}{ll}
\hline Education & Number \\
\hline
\end{tabular}

Primary education 168

Secondary school without graduation exam (A-levels) 1029

Secondary school with graduation exam (A-levels) 3376

University 1427

Number of years in the enterprise Number

less than 1 year 673

1 - 3 years 1356

\begin{tabular}{ll}
\hline $4-6$ years & 1277 \\
\hline $7-9$ years & 1044
\end{tabular}

\begin{tabular}{ll}
$7-9$ years & 1044 \\
\hline 10 years or more & 1650
\end{tabular}

\begin{tabular}{ll}
\hline Position & Number \\
\hline Managers & 342 \\
\hline Workers (labourers) & 3888 \\
\hline Office workers & 1770 \\
\hline Source: authors &
\end{tabular}

$H_{0}: \sigma_{1}^{2}=\sigma_{2}^{2} \quad$ vs. $\quad H 1: \sigma_{1}^{2} \neq \sigma_{2}^{2}$

$\mathrm{H}_{0}$ : It is assumed that the arithmetic means of the selected motivational factors (required and actual, in Slovak enterprises) are equal to each other. It is also assumed that the difference between them, if any, is caused by random fluctuations in the results of choice.

$\mathrm{H}_{1}$ : It is assumed that the arithmetic means of the selected motivational factors (required and actual, in Slovak enterprises) are not equal to each other. It is also assumed that the difference between them, if any, is not caused by random fluctuations in the results of choice.

The random variable $\mathrm{T}$ was used as a testing criterion, resulting in the Student's t-distribution, as shown in Equations 3 and 4:

when $\sigma_{1}^{2}=\sigma_{2}^{2} ; X_{1}$ and $X_{2}$ are independent 
Student's T-test employee motivation level in Slovakia - 2015

Table 2

\begin{tabular}{|c|c|c|c|c|c|c|c|c|c|}
\hline \multicolumn{2}{|c|}{ Motivational factor } & \multirow{2}{*}{$\begin{array}{c}\begin{array}{c}\text { Arithmetic } \\
\text { mean }\end{array} \\
3.35 \\
\end{array}$} & \multirow{2}{*}{$\begin{array}{c}\begin{array}{c}\text { Standard } \\
\text { deviation }\end{array} \\
1.01 \\
\end{array}$} & \multirow[t]{2}{*}{ Number } & \multirow[t]{2}{*}{ Difference } & \multirow[t]{2}{*}{$\begin{array}{l}\text { Standard deviation of } \\
\text { the difference }\end{array}$} & \multirow[t]{2}{*}{$\mathrm{t}$} & \multicolumn{2}{|c|}{$\begin{array}{c}\text { Confidence interval } \\
95 \%\end{array}$} \\
\hline \multirow{2}{*}{ Workplace atmosphere } & $\mathrm{S} 1$ & & & & & & & -1.10 & \\
\hline & P1 & 4.42 & 0.78 & 6000 & -1.1 & 1.15 & -72 & & -1.04 \\
\hline \multirow{2}{*}{ Good team work } & $\mathrm{S} 2$ & 3.49 & 1.00 & & & & & -0.97 & \\
\hline & $\mathbf{P 2}$ & 4.43 & 0.75 & 6000 & -0.9 & 1.07 & -68 & & -0.91 \\
\hline \multirow{2}{*}{$\begin{array}{l}\text { Additional financial } \\
\text { reward }\end{array}$} & $\mathrm{S} 3$ & 2.75 & 1.06 & & & & & -1.60 & \\
\hline & P3 & 4.32 & 0.82 & 6000 & -1.6 & 1.36 & -89 & & -1.53 \\
\hline \multirow{2}{*}{ Physical effort } & $\mathrm{S} 4$ & 3.18 & 0.97 & & & & & -0.71 & \\
\hline & P4 & 3.86 & 0.93 & 6000 & -0.7 & 1.26 & -41 & & -0.64 \\
\hline \multirow{2}{*}{ Job security } & S5 & 3.16 & 1.08 & & & & & -1.32 & \\
\hline & P5 & 4.45 & 0.79 & 6000 & -1.3 & 1.26 & -79 & & -1.26 \\
\hline \multirow{2}{*}{$\begin{array}{c}\text { Workplace } \\
\text { communication }\end{array}$} & S6 & 3.28 & 1.02 & & & & & -1.04 & \\
\hline & P6 & 4.29 & 0.82 & 6000 & -1.0 & 1.18 & -66 & & -0.98 \\
\hline \multirow{2}{*}{ Enterprise name } & S7 & 3.33 & 1.02 & & & & & -0.58 & \\
\hline & P7 & 3.88 & 1.03 & 6000 & -0.5 & 1.20 & -35 & & -0.52 \\
\hline \multirow{2}{*}{$\begin{array}{l}\text { Opportunity to apply } \\
\text { one's own ability }\end{array}$} & S8 & 3.11 & 1.02 & & & & & -0.98 & \\
\hline & P8 & 4.06 & 0.85 & 6000 & -0.9 & 1.18 & -62 & & -0.92 \\
\hline \multirow{2}{*}{$\begin{array}{l}\text { Workload and type of } \\
\text { work }\end{array}$} & S9 & 3.29 & 0.98 & & & & & -0.86 & \\
\hline & P9 & 4.11 & 0.84 & 6000 & -0.8 & 1.14 & -56 & & -0.80 \\
\hline \multirow{2}{*}{$\begin{array}{l}\text { Information about } \\
\text { performance results }\end{array}$} & $\mathrm{S} 10$ & 3.15 & 0.99 & & & & & -0.88 & \\
\hline & $\mathrm{P} 10$ & 4.00 & 0.90 & 6000 & -0.9 & 1.17 & -56 & & -0.82 \\
\hline \multirow{2}{*}{ Working time } & S11 & 3.35 & 1.08 & & & & & -0.90 & \\
\hline & P11 & 4.22 & 0.85 & 6000 & -0.9 & 1,25 & -54 & & -0.84 \\
\hline \multirow{2}{*}{ Work environment } & $\mathrm{S} 12$ & 3.34 & 1.02 & & & & & -0.90 & \\
\hline & $\mathrm{P} 12$ & 4.21 & 0.81 & 6000 & -0.9 & 1.17 & -57 & & -0.84 \\
\hline \multirow{2}{*}{ Work performance } & S13 & 3.38 & 0.95 & & & & & -0.79 & \\
\hline & P13 & 4.14 & 0.82 & 6000 & -0.8 & 1.08 & -55 & & -0.73 \\
\hline \multirow{2}{*}{$\begin{array}{l}\text { Moving up corporate } \\
\text { ladder }\end{array}$} & S14 & 3.16 & 0.98 & & & & & -0.92 & \\
\hline & P14 & 4.05 & 0.87 & 6000 & -0.9 & 1.19 & -58 & & -0.86 \\
\hline \multirow{2}{*}{ Competences } & $\mathrm{S} 15$ & 2.91 & 1.00 & & & & & -1.01 & \\
\hline & P15 & 3.88 & 0.93 & 6000 & -1.0 & 1,28 & -59 & & -0.95 \\
\hline \multirow{2}{*}{ Prestige } & S16 & 3.01 & 0.96 & & & & & -0.76 & \\
\hline & P16 & 3.73 & 1.00 & 6000 & -0.7 & 1.23 & -46 & & -0.69 \\
\hline \multirow{2}{*}{ Supervisor's approach } & S17 & 3.26 & 1.15 & & & & & -1.15 & \\
\hline & P17 & 4.38 & 0.83 & 6000 & -1.1 & 1.28 & -67 & & -1.08 \\
\hline Individual decision & $\mathrm{S} 18$ & 3.08 & 1.02 & & & & & -0.95 & \\
\hline making & P18 & 3.99 & 0.89 & 6000 & -0.9 & 1.21 & -59 & & -0.89 \\
\hline Colf & S19 & 3.04 & 1.02 & & & & & -0.98 & \\
\hline & P19 & 3.98 & 0.89 & 6000 & -0.9 & 1.23 & -59 & & -0.91 \\
\hline
\end{tabular}


Student's T-test employee motivation level in Slovakia - 2015

Table 2

\begin{tabular}{|c|c|c|c|c|c|c|c|c|c|}
\hline \multicolumn{2}{|l|}{ Motivational factor } & \multirow{2}{*}{$\begin{array}{c}\begin{array}{c}\text { Arithmetic } \\
\text { mean }\end{array} \\
2.97\end{array}$} & \multirow{2}{*}{$\begin{array}{c}\begin{array}{c}\text { Standard } \\
\text { deviation }\end{array} \\
1.08\end{array}$} & \multirow[t]{2}{*}{ Number } & \multirow[t]{2}{*}{ Difference } & \multirow[t]{2}{*}{$\begin{array}{l}\text { Standard deviation of } \\
\text { the difference }\end{array}$} & \multirow[t]{2}{*}{$\mathrm{t}$} & \multicolumn{2}{|c|}{$\begin{array}{c}\text { Confidence interval } \\
95 \%\end{array}$} \\
\hline \multirow{2}{*}{ Social benefits } & $\mathrm{S} 20$ & & & & & & & -1.24 & \\
\hline & $\mathrm{P} 20$ & 4.18 & 0.88 & 6000 & -1.2 & 1.34 & -70 & & -1.17 \\
\hline \multirow{2}{*}{ Fair appraisal system } & $\mathrm{S} 21$ & 3.02 & 1.09 & & & & & -1.43 & \\
\hline & P21 & 4.41 & 0.83 & 6000 & -1.4 & 1.31 & -83 & & -1.36 \\
\hline \multirow{2}{*}{ Stress /limitations } & $\mathrm{S} 22$ & 2.91 & 1.01 & & & & & -1.22 & \\
\hline & $\mathrm{P} 22$ & 4.10 & 0.92 & 6000 & -1.2 & 1.34 & -69 & & -1.16 \\
\hline \multirow{2}{*}{ Mental effort } & $\mathrm{S} 23$ & 2.95 & 1.00 & & & & & -1.10 & \\
\hline & $\mathrm{P} 23$ & 4.02 & 0.93 & 6000 & -1.1 & 1.34 & -62 & & -1.04 \\
\hline \multirow{2}{*}{ Enterprise mission } & $\mathrm{S} 24$ & 3.06 & 0.98 & & & & & -0.86 & \\
\hline & $\mathrm{P} 24$ & 3.89 & 0.97 & 6000 & -0.8 & 1.22 & -52 & & -0.79 \\
\hline \multirow{2}{*}{ Region's development } & $\mathrm{S} 25$ & 2.82 & 1.02 & & & & & -1.03 & \\
\hline & $\mathrm{P} 25$ & 3.82 & 1.04 & 6000 & -1.0 & 1.37 & -57 & & -0.97 \\
\hline \multirow{2}{*}{$\begin{array}{l}\text { Education and personal } \\
\text { growth }\end{array}$} & $\mathrm{S} 26$ & 2.94 & 1.03 & & & & & -1.15 & \\
\hline & $\mathrm{P} 26$ & 4.06 & 0.91 & 6000 & -1.1 & 1.26 & -68 & & -1.08 \\
\hline \multirow{2}{*}{$\begin{array}{c}\text { Enterprise relation to } \\
\text { environment }\end{array}$} & S27 & 3.22 & 1.04 & & & & & -0.75 & \\
\hline & $\mathrm{P} 27$ & 3.94 & 1.00 & 6000 & -0.7 & 1.23 & -45 & & -0.69 \\
\hline \multirow{2}{*}{ Free time } & $\mathrm{S} 28$ & 3,08 & 1.05 & & & & & -1.07 & \\
\hline & $\mathrm{P} 28$ & 4,12 & 0.92 & 6000 & -1.0 & 1.29 & -62 & & -1.01 \\
\hline \multirow{2}{*}{ Recognition } & S29 & 2.96 & 1.04 & & & & & -1.25 & \\
\hline & P29 & 4.17 & 0.87 & 6000 & -1.2 & 1.30 & -72 & & -1.18 \\
\hline \multirow{2}{*}{ Basic salary } & $\mathrm{S} 30$ & 2.68 & 1.16 & & & & & -1.91 & \\
\hline & P30 & 4.55 & 0.77 & 6000 & -1.9 & 1.41 & -103 & & -1.84 \\
\hline
\end{tabular}

Note: The important motivational factors are highlighted in bold. $S=$ actual status, $P=$ required status. Source: authors

$$
t=\frac{\bar{x}_{1}-\bar{x}_{2}}{\sqrt{\frac{n_{1} \cdot s_{1}^{2}+n_{2} \cdot s_{2}^{2}}{n_{1}+n_{2}-2} \cdot \frac{n_{1}+n_{2}}{n_{1} \cdot n_{2}}}}
$$

and when $\sigma_{1}^{2} \neq \sigma_{2}^{2} ; X_{1}$ and $X_{2}$ are independent

$$
t=\frac{\bar{x}_{1}-\bar{x}_{2}}{\sqrt{\frac{s_{1}^{2}}{n_{1}-1} \cdot \frac{s_{2}^{2}}{n_{2}-1}}}
$$

At the end of the test we compared $t$ to $t_{\alpha / 2 ; f^{\circ}}$. Where $t \leq t \frac{\alpha}{2}$; we accepted $\mathrm{H}_{0}$ and the tested difference was not considered as significant. Where this was not the case, we rejected $\mathrm{H}_{0}$ at $\alpha \%$ significant level and accepted the alternative hypothesis $\mathrm{H}_{1}$.

\section{Results}

To define the basic levels of motivation, we compared the average actual status (actual perceived level) and average required status (required level) of Slovak employees motivation (see Table 2). The most important motivational factors are highlighted in bold.

The results show that between the required level (P) and the actual level (S) of perceived motivation there are fundamental differences in financial motivational factors (basic salary, additional salary, fair assessment and recognition) and in factors related to interpersonal relationships (workplace atmosphere, workplace communication, access to supervisor, stress, psychological stress). The issue of basic salary was the greatest source of dissatisfaction. All the data are defined at the significance level of $95 \%$.

Each effective motivational program must recognize and evaluate all the factors that affect the work performance of employees. Suitably motivated employees lead to the fulfilment of business objectives and long-term prosperity. Therefore, companies should focus on observing and investigating such motivational aspects which can bring the most satisfaction to their employees. In our research, we defined the motivational factors 
of Slovak employees in 2015, divided according to required and actual factors. Based on the results, we can generally determine the needs of Slovak employees and define problem areas with regards to their motivation. On the basis of these results, we would suggest that managers concentrate on the motivational factors identified when creating their motivational programs.

\section{Conclusion}

On the basis of the results we can conclude that employees are fully aware of the importance of motivational factors (despite the recession) such as job security and of the factors related to human relations. Employees also realize that their employers are not always in a position to provide the required increase in financial remuneration. At present, employers should focus on the process of motivation through motivational factors based on interpersonal relationships and on job security. A more detailed analysis of the individual motivational factors would allow more attractive measures to be adopted that would be more readily accepted by employees, thereby reducing the number of factors which employees deem to be neutral in their work. During the economic crises, many companies do not consider the development and education of their employees as important. This approach is subsequently reflected in the overall future performance levels of enterprises [28 - 30]. For companies, it is important to consider the costs of ongoing education in comparison to the costs of employing someone new in the business. Failure to respect the described results could lead to a significant decline in work performance [29 - 31], a decline in receipts and a rise in business costs.

Creating an appropriate motivational program is a difficult and expensive activity for every business [30 - 32]. Developing such programs requires a thorough and targeted analysis of the motivational requirements of employees. On the basis of our analysis, we can draw the following conclusions. Despite the diversity of employees, for Slovak enterprises, it is possible to design the highly uniform motivational programs that suit the majority of employees. In specific terms, it is possible to carry out a local analysis, the results of which will only differ slightly from the general average. It is also possible that meeting the motivational requirements of employees can initiate their change. For this reason, the motivational programs are to be updated continuously [33-35].

\section{References}

[1] VETRAKOVA, M., POTKANY, M., HITKA, M.: Outsourcing of Facility Management. The J. of Economics and Management. Published by University Liberec, No. 1, 2013, pp. 80-92, ISSN 1212-3609.

[2] ADAIR, J.: The Effective Motivation. Praha: Alfa Publishing, 2004, p. 184, ISBN 80-86851-00-1.

[3] MALACHOVSKY, A.: Goals of Tourism Development in Slovakia in the Context of Regional Development and Selected Tourism Markets, 17 ${ }^{\text {th }}$ Intern. Colloquium on Regional Sciences Location: Hustopece, 2014, pp. 787-795, ISBN: 978-098604193-8.

[4] KACHANAKOVA, A., URBANCOVA, H.: Practical Application of Selected Theoretical Knowledge, Human Resources Management. Economic Annals - XXI, N1-2(1) 2015, ISSN 1728-6220.

[5] STACHO, Z., STACHOVA, K.: Talent Management in Organisations Operating in Slovakia. Economic Annals - XXI, vol. 9-10, No. 1, 2013, pp. 53-57, ISSN 17286220.

[6] GRAZULIS, V., BAZIENE, B.: Employees' Socialization in Lithuanian Preschools - Myth or Reality (situational analysis). Filosofija, Sociologija, vol. 20, No. 4, 2009, pp. 344-353, ISSN 0235-7186.

[7] POTKANY, M., STACHOVA, K.: Required Skills and Abilities of Facility Manager on Strategic Level of Managing in Slovak Companies. Economic Annals - XXI, Institute of Society Transformation, vol. 3-4, No. 1, 2015, pp. 55-59, ISSN 1728-6220.

[8] SEKHAR, CH., PATWARDHAN, M., SINGH, R.: Global Business Perspectives, A Literature Review on Motivation; [online]. Published: 14 November 2013 Intern. Network of Business and Management 2013; Available on: 〈http://link.springer.com/ article/10.1007/s40196-013-0028-1>

[9] KAMPF, R., BUCHACKOVA, P.: User Benefits and Wider Economic Impacts of Infrastructural Project Investment. J. of Information, Control and Management Systems, 3(2), pp. 91-96. ISSN 1336-1716.

[10] VeTRAKOVA, M., DURIAN, J., ElEXOVA, G., SEKOVA, M.: Human Resources and their Management, EF UMB Banska Bystrica: Bratia Sabovci, Zvolen, 2011, p. 275, ISBN 978-80-557-0149-3.

[11] LUCAS, R., MARINOVA, M., KUCEROVA, J., VETRAKOVA, M.: HRM Practice in Emerging Economies: A Long Way to go in the Slovak Hotel Industry? Intern. J. of Human Resource Management, vol. 15, No. 7, November 2004, pp. 1262-1279, ISSN 0958-5192.

[12] KOSTIVIAROVA, S., SOPKOVA, E.: The Evaluation of Innovation Activities of Small and Medium-Sized Business. Perspectives of Innovations, Economics and Business, 2009, No. 3, ISSN 1804-0519. 
[13] HITKA, M. et al.: Human Resources Development II, TU Zvolen, 2013, p. 265, ISBN 978-80-228-2614-3.

[14] KAMPF, R., LIZBETINOVA, L.: The Identification and Development of Talents in the Environment of Logistics Companies. Nase more. University of Dubrovnik, vol. 62, No. Special Issue, 2015, pp. 139-142, ISSN 0469-6255.

[15] REBETAK, M., FARKASOVA, V.: Managing High - Potential Employees, Procedia - Economics and Finance, vol. 23, 2015, [online], pp. 867-871, ISSN 2212-5671. Available on: http://www.sciencedirect.com/science/article/pii/S2212567115004372/ pdf?md5=3448 464b0eaa221ee5575ffb6fc26a8e\&pid=1-s2.0-S2212567115004372-main.pdf

[16] MYSKOVA, R.: The Methodology of Evaluation of Staff Satisfaction. The J. of Economics and Management, 1, 2005, pp. 84-97, TU Liberec, ISSN 1212-3609.

[17] KAMPF, R.: Outsourcing - The Reasons, Advantages and Consequences. Proc. of Economics and Management of Enterprises in 2013, Zvolen: Technical University, pp. 192-196, ISBN 978-80-228-2565-8. 2013.

[18] STANEK, P.: Discovering the Causes of the Economic Crisis [online], published 14.5.2009, available on: http://www. akademickyrepozitar.sk/Peter-Stanek/Odhalenie-pricin-hospodarskej-krizy

[19] KUCHARCIKOVA, A.: The Importance of Identification and Analysis of Educational Needs for Investment in Human Capital. Communications - Scientific Letters University of the Zilina, 16 (3), 2014, pp. 86-92, ISSN 1335-4205.

[20] BRODSKY, Z., MYSKOVA, R.: Internet - Global Information System Supporting the Collection of Labour Market Information, 14 ${ }^{\text {th }}$ WSEAS Intern. Conference on Communications, Part of the $14^{\text {th }}$ WSEAS CSCC Multiconference; Corfu Island: Greece; July 2010, ISBN: 978-960474200-4.

[21] ZAVADSKY, J., HITKA, M. \& POTKANY, M.: Changes of Employee Motivation of Slovak Enterprises Due to Global Economic Crisis, The J. of Economics and Management. Published by University Liberec, vol. 18, No. 1, 2015, pp. 57-66, ISSN 1212-3609. Available on: http://dx.doi.org/10.15240/tul/001/2015-1-005

[22] SUlGAN, M., SOSEDOVA, J.: Procurement of Materials and Components for Manufacturing Activity, Communications - Scientific Letters University of Uilina, vol. 16 (2), 2014, pp. 58-62, ISSN 1335-4205.

[23] BOLFIKOVA, E., HREHOVA, D., FRENOVA, J.: Manager's Decision-making in Organizations - Empirical Analysis of Bureaucratic vs. Learning Approach, proc. Radova Ekonomskog Fakultet au Rijeci 28(1), 2010, pp. 135-163, ISSN 1331-8004.

[24] HITKA, M.: Model of Employee Motivation Analysis of Manufacturing Companies, Zvolen : Technical University, 2009, pp. 150, ISBN 978-80-228-1998-5

[25] STATSOFT. Inc. Statistica (data analysis software system). version 7, 2004. www.statsoft.com.

[26] MASON, R., D., LIND, D., A., MARCHAL, W. G.: Statistical Techniques in Business and Economics, Richard D Irwin; $10^{\text {th }}$ ed., 1998, p. 928, ISBN-10: 0256263078.

[27] SCHEER, L.: Biometrics, Technical University in Zvolen, 2007, ISBN 978-80228-17233.

[28] KAMPF, R., HITKA, M., POTKANY, M.: Interannual Differences of Staff Motivation of Manufacturing Plant in Slovakia, Communications - Scientific Letters University of Zilina, No. 4, 2014, pp. 98-102, ISSN 1335-4205.

[29] WEBEROVA, D.: The Process of Effective Communication in Project Management - $1^{\text {st }}$ ed., Zlin: VeRBuM, 2013, p. 180., ISBN 978-80-87500-32-3.

[30] VODAK, J., SOVIAR, J., LENDEL, V., VARMUS, M. Proposal of Model for Effective Management of Cooperation Activities in Slovak Companies. Communications - Scientific letters University of Zilina, No. 4, 2015, pp. 53-59, ISSN 1335-42054.

[31] Rosova, A., BALOG, M., SIMEKOVA, Z.: The Use of the RFID in Rail Freight Transport in the World as One of the New Technologies of Identification and Communication. Acta Montanistica Slovaca, vol. 18, No. 1, 2013, pp. 26-32, ISSN 1335-1788.

[32] KUBASAKOVA, I., KAMPF, R., STOPKA, O.: Logistics Information and Communication Technology. Communications - Scientific Letters University of Zilina. vol. 16, No. 2, 2014, pp. 9-13, ISSN: 1335-4205.

[33] PRUSA, P., TILKERIDIS, D.: Possibilities of Logistics Policy Improvement, Promet, vol. 21, No. 21, 2009, pp. 123-127, ISSN 03535320.

[34] KRILE, S., PERAKOVIC, D., REMEnAR, V.: Possible Collision Avoidance with Off-Line Route Selection, Promet \& Transportation, vol. 21, No. 6, 2009, pp. 415-423, Portoroz : Trieste : Zagreb, ISSN 0353-5320.

[35] STOPKA, O., BARTUSKA. L., KAMPF, R: Passengers' Evaluation of the Integrated Transport Systems, Nase More, vol. 62, 2015, pp. 153-157, ISSN 0469-6255. 